\title{
Using Pick and Speak Board Game to Enhance Pupils' Speaking Skill
}

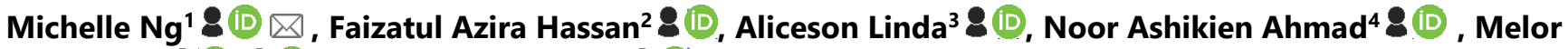 \\ Md Yunus ${ }^{5}$ (D) 8(D) and Ashairi Suliman ${ }^{6}$ (D) \\ ${ }^{123456}$ Faculty of Education, Universiti Kebangsaan Malaysia, Bangi, Malaysia
}

$\triangle$ Corresponding Author: Michelle Ng, E-mail: michellecatherynna@gmail.com

\section{ARTICLE INFORMATION}

Received: May 09, 2021

Accepted: June 08, 2021

Volume: 3

Issue: 7

DOI: 10.32996/jeltal.2021.3.7.3

\section{KEYWORDS}

Board game, speaking skill, quasiexperimental research, teaching aids, technology enhance language learning, English language education

\section{ABSTRACT}

English as a Second Language emerges as an essential language to acquire and impacts most of the education system. The scenario also requires our young learners to master the language to polish their interpersonal and communication skills to prepare them for a developing nation. This research aims to study whether using the Pick and Speak board game can help enhance speaking skills among primary school pupils. The research applied quasi-experimental research to obtain data. 67 Year 3 pupils from four suburban schools in Sarawak were identified as the research sample. The researchers grouped them into high achievers, intermediate and low achievers. Pupils were given questionnaires to get their feedback to support the data finding from the pre-test and post-test. With the aid of this board game intervention, pupils are expected to construct sentences using present continuous tense and describe their daily routines orally. The study indicated that using Pick and Speak board game impacts pupils' speaking performance, especially in vocabulary and pronunciation, followed by grammar and fluency aspects during the learning process. The researchers hoped that this board game innovation would benefit both the teachers and young learners as the alternative teaching aid to teach and develop their speaking skills with grammatical errors free. Most importantly, the Pick and Speak board game offers an effective way of improving teaching efficiency, encouraging the element of collaborative and competition in a non-threatening environment.

\section{Introduction}

During this global digital era, English has been the language widely spoken in any formal or informal occasion to deliver and convey messages. The young generations nowadays are urged to actively enhance themselves in English language proficiency in line with the transformation of the 21st Learning Century. Learning to speak English benefits those who understand it, especially for gaining knowledge and elevating skills, but also exposes one to career opportunities worldwide. Those people who know the language will not face difficulties when they travel to communicate and interact with others from other parts of the world (Garg \& Gautam, 2015). The opportunity to learn, read, write and speak English is an additional advantage for all. Since many resources are available such as the internet, social media, mass media, and reading materials, making the English language much easier to acquire.

Nevertheless, learning English as a second language is less easy for those learning it outside of English-speaking countries. Erben, Ban \& Castaneda (2008) recommend that five principles be considered to create effective dual language learning environments and related educational activities. The first principle is that the English Language Learners (ELLs) should be given a lot of chance "to read, write, listen to, and discuss oral and written English texts expressed in various ways". The second principle is to "draw attention to patterns of English language structure. The third principle is the teachers should give time to the ELLs to practice their English effectively. The fourth principle is that ELLs should be given chances to "notice their errors and correct their English". The last one is to "construct activities that maximise opportunities for ELLs to interact with others in English" (p. 8).

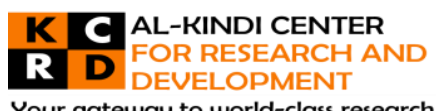

Your gateway to world-class research

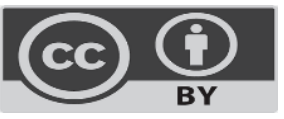

Published by Al-Kindi Center for Research and Development, United Kingdom. Copyright (c) the author(s). This open access article is distributed under a Creative Commons Attribution (CC-BY) 4.0 license 
However, speaking skill in the English Language is frequently the most fearful part of dealing with among Malaysian young learners in the teaching and learning context. Bueno, Madrid and McLaren (2006) supported by stated that speaking is the most difficult skill for language learners. Although the language is learned for so many years, learners found it difficult to speak in reallife situations when required. Noori and $\mathrm{Ng}$ (2013) noted that learners' cognitive and affective parts keep in mind in their language learning experience are their beliefs and perception. The past research discovered that there are many worries that the students' experience in speaking English. For example, Gopal and Wei (2018) stated that "... fear of making mistakes, fear of being laughed at by their friend as they have no idea about pronunciation and grammar that they use" (p. 220). Derakhshan et al. (2015) agreed that the inconsistency between class and course goals often holds up their opportunities for authentic practice. Speaking in English requires pupils" active participation in the classroom during oral tasks in teaching and learning. Malaysian young learners have been exposed to learn the English language for years. Yet, the fact is that there are still many young learners in some of the rural and suburban schools who are not able to speak English fluently and being passive in class during the English language lesson. Anthony and Abdul (2012) found out that the students have low self-confidence regarding oral communication in English. The scenario has become a severe issue as it will affect how they acquire the language well and be progressive towards language proficiency. Our Malaysian National Education Blueprint 2013-2025 intends to create a transformation to overcome the weaknesses of English language proficiency among graduates. As claimed by the Ministry of Education Malaysia (2015), spoken English is a skill that requires urgent upgrading to serve the purpose of national desires and to uplift the graduates" employability.

Speaking skills involve pronunciation and social expression and expressing opinions and ideas smoothly and confidently. Therefore, the use of integrated teaching materials can help to boost our learners" interest, motivation, confidence and fluency in expressing their point of view and ideas through speaking. Because of this speaking skill issue, research has been done regarding the use of intervened board game called Pick and Speak as a teaching and learning material to improve pupils" language proficiency in constructing sentences orally using Subject-Verb Agreement. Pick and Speak is an editable board game that can be both in soft copy and hard copy. According to Chang and Hwang (2019), board games in the language classroom can be effective, low-anxiety, and enjoyable for students to learn and practice speaking skills. Board games also develop the students' communication strategies that can be ready to apply in their daily lives and global economic purposes. Marzano (2007) also points out that "Human beings are typically interested in puzzles and games even though they may be of little consequence in terms of long-term goals or deeply held values ..." (p. 101). A QR code version has been created to make it convenient to apply. Resnick (2007) spelt out that "... the changes in technology all around us can both demand creativity and flexibility to adapt, and also provides tools to allow more creative activities" (p. 229). Myhill et al. (2012) emphasized that to assist children in familiarizing specific aspects of language for certain effects, it is advisable to clearly and in detail the teaching of Englishlanguage features that apply "discussion, exploration, investigation, and experimentation".

The research aims to study the use of the Pick and Speak board game to enhance speaking skills by taking into account the four speaking components: fluency, pronunciation, vocabulary, and grammar among primary school pupils. The study also intended to observe whether the use of the Pick and Speak board game can enhance the pupils' speaking skills by practising SubjectVerb-Agreement in constructing sentences orally.

\section{Literature Review}

\subsection{Using board game in ESL classroom}

Teaching and learning have rapidly changed in this current world, and 21st-century learning has been emphasized to cater to students in this challenging world per se communicative skill. However, students nowadays are lack interest to learn the English language in school due to many reasons. According to Larasati et al. (2019), a teacher should attract students" interest by providing the students with interesting teaching aids during the lesson that will motivate the students to be less anxious in the teaching and learning process. Harmer (2016) stated that "Motivation means a kind of drive that encourages somebody to pursue a course of action." The learners will be motivated and interested in learning the English language. Board games will usually increase positive feelings among the learners and will improve their self-confidence as well. This is because there would be no fear of punishment and criticism while they are practicing the language freely. Chang and Cogwell (2008) stated that board games could be an effective and meaningful tool for teaching and learning as long as the board games are aligned with the national curriculum and match specific learning objectives. While Schwarz and Braff (2011) stated that learners could learn all the language skills better through games. In this context also, vocabulary is one of the important language components that should not be forgotten. As agreed by Smith (2006), "Vocabulary teaching, especially in the initial stages of learning, plays a crucial role in foreign language learning" (p.4). Further, the previous study by Dewi et al. (2016) also agreed that "...using the communicative game as means of instructions improved the students" achievement and results of speaking skill" (p. 69).

Meanwhile, Akdogan (2017) stated that games should give many vocabulary inputs for the learners to enhance their speaking skills through playing. Aside from that, according to Schwarz and Braff(2011), the benefit of using board games in the ESL 
classroom is that they promote turn-taking skills among the players, which can help to create a friendly environment that includes cooperative learning, friendly competition, fun, creativity, and curiosity. Sujay and Smriti (2016) also believed that learners could learn the English language without knowing that they are learning and be less anxious through games.

\subsection{Using board games to enhance speaking skill performance among student}

The proper technique that involves students in the classroom activity can create a communicative classroom that supports the improvement of speaking ability. According to Azzahroh (2015), by applying the students in classroom activities, they can build interactive activities like talking to each other using English, the target language. One of the communicative activities that the students can implement is by using a board game. As stated in Azzahroh (2015), the term "board game" can be defined as a game that involves counters or pieces moved or placed on a pre-marked surface or "board", according to a set of rules. Thus, Azzahroh (2015) agreed that in using games to teach, the students would be able to get other functions of games besides mastering speaking skills. According to Mayer and Harris(2002), board games can help students gain various life skills, including authentic experience, student engagement, social and life skills, and higher-order thinking. In the context of teaching speaking through a board game, Azzahroh (2015) also reviewed Rahmawati's (2012) thesis, "Improving the Fourth Grade Students' Speaking Skill through Board Game". Rahmawati(2012) concluded that teaching English through board games was reasonable and improved the students' speaking skills. The results of the study by Rahmawati (2012) also showed that the use of board games in combination with applying various media in the presentation, using songs, using classroom English and conducting listening activities was also able to improve students" speaking skills (Azzahroh, 2015).

Yunus (2007) also had done one study on the effects of the board game on the speaking ability of low-proficiency ESL Learners. The board game "What Say You" had been implemented in their study. The results from the experimental and control groups showed a significant difference in the pre-and post-treatment speaking test scores. Their research also showed the speaking performance of the experimental group revealed significantly higher scores. Yunus (2007) also stated that initially hesitant and passive students were more willing to speak and present and justify their ideas more confidently compared to the control group after the treatment. Besides, in the research findings, Cut et al. (2016) showed that using a board game can im-prove speaking skills for the students. They have assumed that board games improve speaking components (vocabulary, fluency, grammar, and pronunciation). Thus, playing a board game is one of the helpful techniques that can enhance students' speaking skills is one of the helpful technique that can enhance students' speaking skills.

\subsection{Application of technology along with board game (digital board game)}

As stated by Yunus and Suliman (2014), "ICT supports the modern principles of learning and language acquisition" (p.6). The digital board game as a teaching aid is very convenient if it is portable and can be taken everywhere. The usage of the digital board game is relevant to create and sustain teaching and learning among students inside and outside the classroom. At present, digital board games, for instance, mobile board games, can be downloaded from various applications available in the Google play store for Android users and Apple Apps store iPhone (iOS) users. As sup-ported by Zulkhairi et al. (2010, as cited in Halili \& Sulaiman, 2018), board game inspires children of various age groups to collaborate as they need to do all the time in their life. Thus, by having digital board games downloaded and installed via a computer or mobile phone, parents with the child can collaborate to solve the board games on the devices. In a way, it strengthens the bonding between them while enjoying the moment within a relaxing environment. Cheung and McBride(2017) found that children in the "Game with parent training" group improved more than children in the "Game without parent training" group on all four outcome measures (rote counting, numerical identification, mathematics interest, and addition) after a 4-week intervention. Each intervention included two 15minute sessions per week as set by the researchers. Other researchers, Yong and Yeo (2016), also claimed that when there are more people involved, more positive emotions are produced, which will encourage the play and thus lead to creating an even more positive feeling. According to Putri(2018), a board game could help students improve their speaking skills. Results showed significant differences in speaking skills among the students after being taught using board games.

According to Ali et al. (2017), "Technology will not only help us to design better games but will also allow us to create effective new learning opportunities and tools" (p. 1). At the same time, most digital board games can encourage students to think strategically by requiring them to plan a strategy while playing. It correspondingly helps to boost one's patience besides focusing on developing techniques and goals. Some games take hours to complete. To do so, one needs to remain patient until the end of the game (Hall, n.d.). Bologna (2019) suggested that playing board games is an alternative way to learn to build rapport with everybody. In other words, playing board games help to develop emotional intelligence among the players. Throughout playing the board games, the players will learn to be aware of their feelings and have self-control on words and actions that might hurt others. Subsequently, it would turn up to be a valuable process of lifelong learning, especially when it comes to learning and acquiring language along the way while playing the board game. 


\subsection{Benefits of using ICT}

Yunus et al. (2013) mentioned that students would open up to more learning opportunities to learn the language using ICT. A study by Yunus and Azman (2019) also showed that ICT could help develop the teaching and learning process. By integrating board games with technology, the teacher can edit the board game by inserting and changing the words, pictures, and grammar items to suit the pupils' learning needs. It makes even more sense if existing teaching and learning use either of these educational applications to make even monotonous and complex grammar parts more exciting and related to the learners, particularly the young ones (Zander, 2019). Another benefit of using ICT in the teaching and learning process is that Chaudari (2013) stated a change from a traditional authoritative role to a facilitator, whereby teachers will only facilitate the whole process while the learners will be more independent responsibility for their learning. Language teachers also could provide individual and personalised guidance to the learners. Language learners could also benefit from using a few media audio, videos, authentic contents, and real-world experiences with different learning styles.

A QR (Quick Response) code and soft copy version are available to make it more fun learning, whereby the board game acts like a chess mat. As stated in Petrova et al. (2016), "QR codes can be created easily and cheaply, often at no cost". For that reason, QR codes can save teacher"s time, save space and expose the learners to applications. Bakla (2018) also agreed that both teachers and learners could quickly generate the QR code without much practice. Hence, the QR code can be an application that promotes active learning in the classroom. As revealed in a study by Rikala and Kankaanranta (2012, as cited in M. Specht et al., 2012), the learners were eager and motivated to learn and use the QR codes. The study found that the QR codes could draw their attention to the lesson since the codes support learning and allow learners to be independent and cooperative in the learning process. Besides, the QR codes should support the learners to access the information independently. It could be a handy tool for teachers to teach language as they could share answers, new words, pronunciations, audios, videos, videos, spelling, and more information. Therefore, the QR code is an essential element to be developed in the board game to initiate 21st-century learning in the classroom.

\subsection{Challenges faced in using ICT}

Although ICT has many benefits to be implemented in the classroom, there are also challenges in using ICT. As for the schools with no access to the Internet could have difficulty integrating the technology in using the board. As Yunus et al. (2009) stated, many factors challenge the students in the process to learn a language, and one of the factors is the school environment. The school environment must be conducive and equipped with facilities that can provide long-term learning resources to smooth teaching and learning. However, most rural areas have inadequate facilities such as computer labs, internet coverage, and a netbook. The main issue is that students are not allowed to bring smartphones to school. Therefore, this will be a hindrance to use ICT in the classroom. Furthermore, there is a time constraint for setting up the projector, which causes the students to lose interest in language learning.

Due to specific issues, it would be more challenging for rural school teachers and students to integrate ICT in teaching and learning. There is still a digital gap of limited computer literacy in students from indigenous, lower socio-economic or regional/rural backgrounds (Hyndman, 2018). In terms of organizational aspects, most of the students in rural schools are lack interest and expertise in integrating ICT. There is no urge to develop in ICT due to the low quality of the internet services provided by the communication service centre. Most of the private sectors also lack interest in developing and maintaining ICT in rural areas since it is cosy, long-distance to approach, and the risk of losing profits.

According to Schmitt (2010), the rural community faced problems and challenges mainly regarding the limited infrastructures, unaffordability to buy ICT equipment, lack of knowledge, skills, and training in using the ICT tools. Zulkhairi et al. (2010) stated that literacy and broadband penetration rates are still low in less than one per cent in rural areas. This condition shows that both the cellular and Wi-Fi internet coverage in rural areas is still in abysmal performance. Subsequently, it can easily demotivate the teaching and learning concentration among the whole community surrounds. Moreover, despite recent attempts to incorporate ICT into classrooms, many families still do not know about using ICT resources in their everyday lives, especially in rural areas. Not all households have routine use of computers and Internet facilities (Ghavifekr et al., 2016). Therefore, the authorities hope to help provide better equipment to expand ICT use in the future, especially in rural areas.

\section{Methodology \\ 3.1. Research Design}

This research applied the quasi-experimental research design. According to Cook and Campbell (1979), quasi-experimental research implies manipulating an independent variable without the random assignment of participants to conditions or orders of the states. This research aims to study the impact of using the Pick and Speak board game in enhancing speaking skills among primary school pupils, and thus, the data collection was done quantitatively. The use of the Pick and Speak board game is the independent variable $(\mathrm{X})$ of the research; meanwhile, the speaking skill performance is the dependent variable $(\mathrm{Y})$. Therefore, the 
speaking skill performance score was used to indicate that the use of the Pick and Speak board game can enhance pupils' speaking skills.

Table 1. Pretest-posttest design

\begin{tabular}{llll}
\hline & Pre-test & Post- test & Treatment \\
\hline Participants & A & O & $X$ \\
\hline
\end{tabular}

Information of Table 1:

A : Speaking Pretest

O : Class treatment with 'Pick and Speak' board game

$\mathrm{X} \quad$ : Speaking Posttest

\subsection{Research Sample}

Four teachers from four National Primary Schools in suburban Sarawak, Malaysia, conducted the research. The schools are SKT, SKF, SKL, and SKH. Those teachers had encountered a similar problem among the pupils who are lacking proficiency in speaking. This study employed purposive sampling to select the research participants. According to Fraenkel, Wallen, and Hyun(2012), the researchers rely on their judgment to choose a sample, unlike convenience sampling. It will also provide necessary data as required based on their past knowledge, known as purposive sampling. There were 67 participants of Year 3 pupils from the four schools involved in this research; without any controlled group. The level of proficiency of the participants in this research was from low to high. It will also provide necessary data as required based on their past knowledge, known as purposive sampling. There were 67 participants of Year 3 pupils from the four schools involved in this research; without any controlled group. The level of proficiency of the participants in this research was from low to high.

\subsection{Research Instruments}

The instruments used in this research were pre-test, post-test, and questionnaire. The pre-test, which consists of five questions, was given before the treatment and followed by three intervention sessions. Meanwhile, during the last intervention session, the post-test was administered. In addition, the students were given questionnaires after the treatment. Followed this, a post-test has been undertaken to obtain feedback on the Pick and Speak board game. The questionnaire, adapted from Kementerian Pendidikan Malaysia (n.d.), consisted of five items with the scale from 'A little', 'Okay' and 'Very Great'. The information was gathered, analyzed, and presented using percentages.

\subsection{Research Procedures}

This study was conducted within two weeks, which was twice a week during the English Language lesson. According to the Ministry of Education's guidelines, the duration for each lesson was one hour. The researchers conducted four lessons specifically for this study.

For the planning stage, analyzing pupils' learning problems by considering the need to overcome the problem has been done and later transferred in the problem statements. A determined target group and the duration to conduct the study were also included during this stage. During the designing stage, several drafts of samples for the board game, consisting of lists of targeted vocabularies (action verbs), were created via discussion among the four teachers. The researchers decided the primary source of the vocabularies taken from the current Year 3 CEFR-aligned curriculum textbook entitled 'Get Smart' and the curriculum syllabus.

The board games are available in two formats: manual and digital (Microsoft Power-Point). The next step was developing the lesson plans. The teachers-in-charge (researchers) introduced sentence structures and verbs to the pupils during the first lesson. The researchers performed the implementation on the intervention stage during the second, third and fourth lessons. During the second lesson, the manual board games were introduced as a practice stage to prepare the pupils to play the digital version, which they managed to do during the third and fourth lessons. The second and third lessons were the treatment stage applied in this research. The post-speaking test took place during the fourth lesson, followed by handed out the questionnaire after that lesson.

The data gathered through the test were classified, organized, tallied and tabulated. Then, the researchers treated the data to answer the research objective. The overall score and percentage were calculated based on the four speaking components for the speaking pre-test and post-test. For the questionnaire result, the data - presented using percentage, gained from collecting the total marks of the feedback on the Pick and Speak board game from the participants based on the three criteria: A Little, Okay, and Very Great. 


\subsubsection{Procedures to play the game}

(A) Manual version (board)

i. $\quad$ Players play in minimum with 2 persons or groups of 5 (according to their proficiency levels).

Set A: Advanced, Set B: Beginner).

ii. Players review the vocabulary lists needed to playthe game.

iii. Players take turn to pick the ice-cream stick (question number) and then construct sentences using the words or pictures given. For example - I am dancing.

iv. Players check their answers using the cue cards provided and award marks as followed:

- 5 marks - Subject + Verb

- 10 marks - Subject + Verb + Agreement

- 0 mark - Not answering or inaccurate answer

(B) Digital version (MicrosoftPowerPoint)

i. Click the 'Pick and Speak Game' application.

ii. Players select the board: Set A (Advanced), Set B (Beginner)

iii. Players review the vocabulary lists needed to play the game.

iv Players click on the question number and provide their answer orally based on the clues (pictures/words) that appear

on the screen.

v.Players check their answers using the cue cards provided and award marks as followed:

- 5 marks - Subject + Verb

- 10 marks - Subject + Verb + Agreement

- 0 mark - Not answering or inaccurate answer

\subsubsection{Procedures of conducting the research}

Step 1 : Introduction of the structure of Subject-verb Agreement (SVA).

Step 2 : Pupils were given pre-test before the treatment.

Step 3 : In groups, pupils were playing the manual 'Pick and Speak' board game during the first session of the treatment.

Step 4 : Individually, pupils took turns to play the digital "Pick and Speak' board game during the second and third session of the treatment.

Step 5 : Pupils were given post-test after the treatment.

Figure1.Introduction to SVA structure.

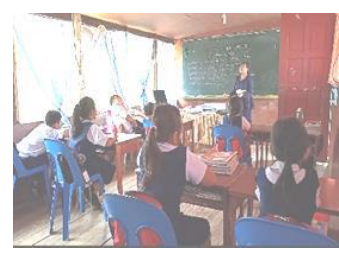

Figure 2 : Pre-test

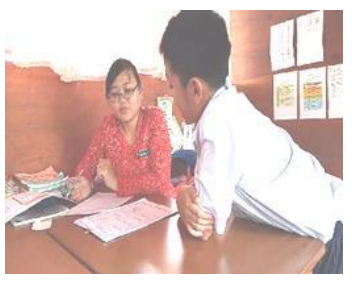

Figure 3 : Playing manual version of 'PickandSpeak' board game 


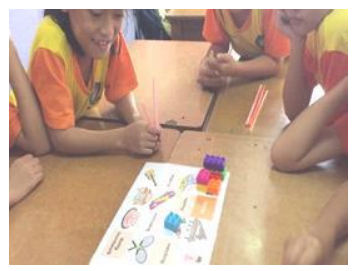

Figure 4 : Playing digital version of "Pick and Speak' board game

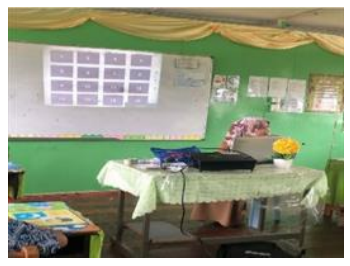

Figure 5 : Post-test

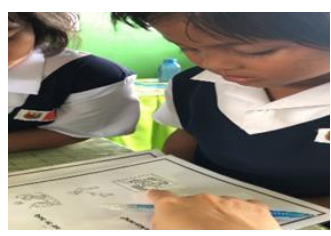

\section{Findings and Discussion}

The first part of the findings presented the progress of each criterion analysed during the speaking pre-test and post-test. The second part of the findings reported the feedback gained from the pupils about the Pick and Speak board game through a questionnaire.

\subsection{Progress of each criterion analysed during the speaking pre-test and post-test.}

Table 2. Overall result for speaking skills

\begin{tabular}{|c|c|c|c|c|c|c|}
\hline $\begin{array}{l}\text { Pre-test } \\
\text { score }\end{array}$ & Score & $\begin{array}{l}\text { Percentage } \\
(\%)\end{array}$ & $\begin{array}{l}\text { Post-test } \\
\text { score }\end{array}$ & Score & $\begin{array}{l}\text { Percentage } \\
(\%)\end{array}$ & $\begin{array}{l}\text { Improvement } \\
\text { Percentage } \\
(\%)\end{array}$ \\
\hline Fluency & 155 & 46.3 & Fluency & 190 & 56.7 & 10.7 \\
\hline $\begin{array}{l}\text { Pronunciati } \\
\text { on }\end{array}$ & 175 & 52.2 & $\begin{array}{l}\text { Pronunciat } \\
\text { ion }\end{array}$ & 227 & 67.8 & 15.5 \\
\hline Vocabulary & 176 & 52.5 & $\begin{array}{l}\text { Vocabular } \\
\text { y }\end{array}$ & 231 & 69.0 & 16.4 \\
\hline Grammar & 171 & 51.0 & Grammar & 210 & 62.7 & 11.6 \\
\hline
\end{tabular}

Table 2 illustrates the overall result for the speaking skill that involved the four schools. To evaluate the speaking skill, the researchers focused on four criteria: fluency, pronunciation, vocabulary, and grammar. During the pre-test and post-test, the participants' speaking abilities were assessed using five questions. The data, shows that all the participants showed improvement after the implementation of the board game. There is an increment of $10.7 \%$ (35 scores) for the pupils' fluency, followed by 11.6 $\%$ (39 scores) in terms of pupils' grammar. In Yunus (2007) research findings, they have stated that board games are a powerful tool when used purposefully although students may not demonstrate uniform improvement in their scores. However, in their research, one improvement was in the student's fluency when carrying out the task set in the post-test. Thus, the board game is also helping in improving students' fluency in speaking skills. For the pupils' pronunciation, there is an increment of $15.5 \%$ (52 scores). Cut, Bustami and Chairina (2016) also had done a quantitative study about a board game to develop students' speaking skills. In terms of pronunciation, a survey by Cut, Bustami and Chairina's (2016) result showed that hypothesis testing of the students' pronunciation performance is significantly improved. They had concluded that the technique improved students' speaking skills in the target language and their accuracy. 
The above findings show that there is a $16.4 \%$ (55 scores) increment in the participants' vocabulary after the implementation of the board game, which made it the highest criterion acquired by the participants among the four criteria. Smith (2006) claimed that vocabulary teaching, mainly in the initial stages of learning, plays a crucial role in foreign language learning. Therefore, the findings show that this Pick and Speak board game has helped the participants improve their vocabulary knowledge. The previous study by Dewi, Kultsum and Armadi (2016) also agreed that using the communicative game as a way of teaching increased the achievement of the students and the outcomes of speaking abilities (p. 69). Moreover, Akdogan (2017) believed that games could provide learners with many vocabulary inputs to develop their speech skills through play. The learners do not need to work hard to memorize the vocabulary. Instead, the learners can comprehend the vocabularies by relating them to their contexts by playing the board game. Hence, this technique could enhance their vocabulary acquisition, motivate and provide enjoyable learning for the learners.

\subsection{Feedback gained from the participants about the Pick and Speak board game}

Table 3. Participants' feedback on the impact of the board game

\begin{tabular}{|c|c|c|c|}
\hline $\begin{array}{l}\text { Statements } \\
\text { After playing the board game, I know how to: }\end{array}$ & A little & Okay & $\begin{array}{l}\text { Very } \\
\text { Great }\end{array}$ \\
\hline a. Say what I'm doing now & 3 & 28 & 36 \\
\hline b. Say what other people are doing & 8 & 29 & 30 \\
\hline c. Talk about different activities & 15 & 19 & 34 \\
\hline d. Talk about jobs to do in the house & 9 & 17 & 41 \\
\hline $\begin{array}{l}\text { e. Construct at least } 3 \text { correct sentences by using } \\
\text { verb with 'ing' }\end{array}$ & 8 & 21 & 38 \\
\hline Total answers & 43 & 114 & 179 \\
\hline Percentage (\%) & 12.8 & 34.0 & 53.4 \\
\hline
\end{tabular}

Table 3 illustrates the data collected from the questionnaires. The researchers used five statements (items) to get feedback from the participants on the impact of the board game on them. The feedback gathered was rated using the category 'A little', 'Okay' and 'Very Great'. A total of 43 (12.8\%) responses agreed with the item in the category of 'A little,' $114(34.0 \%)$ responses agreed with the item in the category of 'Okay,' and 179 (53.4\%) responses agreed with the item in the category of 'Very Great.' The agreed statement showed that $53.4 \%$ of the participants could fulfill the criteria as stated in the information above. 41 participants or $61.2 \%$ have decided that they could talk about jobs in the house after playing the board game, followed by 38 $(56.7 \%)$ of them stating that they could construct at least 3 sentences using verbs with 'ing'.

The data above shows that the board game's implementation had brought positive feedback in enhancing the participants' speaking performance. Indirectly, integration of ICT - implementing QR code and digital version of the Pick and Speak board game is also viewed as beneficial techniques that lead to the participants' intrinsic motivation to speak and hinder their fear of making mistakes while playing the board game. Yong and Yeo (2016) claimed that "The more people play, the more positive emotions are generated, which in turn makes play easier and thus helps to generate even more positive emotion" (p.214). As a result, the researchers found out that $53.4 \%$ of participants have confidently claimed that they felt 'Very Great' as they agreed to the five items shown above. Putri's (2018) study also discovered a similar result where there was a significant difference in students' speaking skills after being taught using the board games, whereby she also concluded that board game could be used to improve students' speaking skills.

\section{Conclusion}

The research employed a quasi-experimental research design to study whether the use of the Pick and Speak board game can help in enhancing speaking skills among the primary school pupils based on the four speaking components as mentioned earlier namely vocabulary fluency, pronunciation, and grammar.

After applied the board game in language learning, the finding shows that using Pick and Speak board game can enhance the pupils' speaking skills based on some increment showed during the post-test, especially on the vocabulary knowledge. Besides, 
the use of the Pick and Speak board game also had shown a significant impact on their fluency, pronunciation, and grammar (Subject-Verb Agreement) during the learning process. It is believed that this game is a helpful material to enhance pupils' speaking skills in the long run if the pupils keep practicing and utilizing the board game in their learning.

To conclude, Pick and Speak board game can enhance pupils' speaking skills and teach grammar items such as Subject-Verb Agreement. For further research, other researchers can use board games to analyse the enhancement of speaking skill by using different grammar items and apply other interesting technology integration in the language learning classroom. This study has two limitations: the possibility of QR-code ineffectiveness and time constraints. The manual version of the Pick and Speak board game includes a QR code. However, it is only useful in schools that do not have access to the internet and for those who do not have a compatible mobile phone. Researchers could probably invent cue cards to replace the clues that appear on the mobile phone's screen when we scan the QR-code in the future. Our goal is to get them to speak and actively learn to construct the Subject-Verb-Agreement sentences besides the main vocabulary. Replacing the QR-code with cue cards will pique their interest in learning meaningfully. Another limitation would be the study's time constraints. The study was completed in two weeks, according to the research procedure section (refer 3.4). Thus, in future research, the researchers could extend the time spent playing the board game by modifying some items (illustrations and vocabulary) to ensure that the pupils actually practice their speaking skills. It is hoped that Pick and Speak board game can be multipurpose teaching aids for ESL teachers to teach grammar items and increase pupils' proficiency, confidence level and motivation to tell oral stories and give speeches spontaneously.

Funding: This research received no external funding.

Conflicts of Interest: The authors declare no conflict of interest regarding the publication of this paper

\section{References}

[1] Akdogan, E. (2017). Developing Vocabulary in Game Activities and Game Materials. Journal of Teaching and Education, 7, 31-66. https://www.academia.edu/35587945/DEVE LOPING_VOCABULARY_IN_GAME_ACTIVITIES_AND_GAME_MATERIALS

[2] Ali Z., Ghazali, M. A. I. M., Ismail, R., Muhammad, N. N., Abidin, N. A. Z., Malek, N. A. (2017). Digital Board Game: Is There A Need for It in Language Learning Among Tertiary Level?. MATEC Web of Conferences (MUCET 2017), Universiti Malaysia Pahang, Malaysia. 150, $2018,1-5$. https://doi.org/10.1051/matecconf/201815

[3] Anthony, E. M. \& Abdul, K. Z. (2012). A Road Not Taken: A Breakthrough in English for Specific Purposes via Problem-Based Learning. Journal of Technical Education and Training, 4, 51-71. https://publisher.uthm.edu.my/ojs/ index.php/JTET/article/view/485

[4] Azzahroh, R. A. (2015). The Effectiveness of Using Board Games Towards Students' Speaking Skill (A Quasi Experimental Study at the Tenth Grade Students of SMAN 1 Parung) [Unpublished Undergraduate Thesis, State Islamic University Syarif Hidayatullah].

http://repository.uinjkt.ac.id/dspace/bitstream/123456789/29253/1/RIZKY\%20AMALIA\%20AZZAHROH-FITK. pdf.

[5] Bakla, A. (2018). Quick Response Codes in Foreign Language Instruction: Practical Ideas and Strategies. Inonu University. Journal of the Faculty of Education, 19, 749-762. doi:10.17 679/inuefd.475262.

[6] Bologna, C. (2019). How to Teach Your Kids to Care About Other People. Huffpost. https://www.huffpost.com/entry/how-to-teach-your-kidsto-careaboutotherpeople_n_5b29cc2ce4b05d6c16 c8c089

[7] Bueno, A., Madrid, D., \& McLaren, N. (2006). TEFL in Secondary Education. Granada: Ed-itorial Universidad de Granada.

[8] Chang, C. Y., \& Hwang, G. J. (2019). Trends in Digital Game-Based Learning in the Mobile Era: A Systematic Review of Journal Publications from 2007 to 2016. International Journal of Learning and Organisation, 13, 68-90. doi: 10.1504/ ijmlo.2019.10016 603

[9] Chang, S \& Cogwell, J. (2008). Using Board Game in the Language Classroom. New York: TESOL Convention and Exhibition.

[10] Chaudari, H. S. (2013). Experiments with Some ICT Tools to Enhance Communication Skill among Undergraduate Students. International Journal for Research in Education, 2, 138-144. http://www.raijmr.com/ijre/wp-content/uploads/ 2017/11/IJRE_2013_vol02_issue_02_23.pdf [11] Cheung, S. K., \& McBride, C. (2017). Effectiveness of Parent-Child Number Board Game Playing in Promoting Chinese Kindergarteners' Numeracy Skills and Mathematics Interest. Early Education and Development, 28, 572-589. doi: 10.1080/104092 89.2016.1258932

[12] Cut, R.P., Bustami, U. \& Chairina N. (2016). Board Game in Speaking Skill. Research in English and Education (READ), 1, $146-151$. http://jim.unsyiah.ac.id/READ/article/view/2583

[13] Cook, T. D., \& Campbell, D. T. (1979). Quasi-Experimentation: Design and Analysis Issues for Field Settings. Boston: Houghton Mifflin. [14] Derakhshan, A., Tahery, F., \& Mirarab, N. (2015). Helping Adults and Young Learners to Communicate in Speaking Classes with Confidence. Mediterranean Journal of Social Sciences, 6, 520-525. doi: 10.5901/mjss.2015.v6n2p520.

[15] Dewi, R. S., Kultsum, U., \& Armadi, A. (2016). Using Communicative Games in Improving Students' Skills. English Language Teaching. Canadian Centre of Science and Education, 10, 63-71. doi: 10.5539/elt.v10n1p63

[16] Erben, T., Ban. R. \& Castaneda, M. (2008). Teaching English Language Learners through Technology (1st ed). NY: Routledge.

[17] Fraenkel, J. R., Wallen, N. E., \& Hyun, H. H. (2012). How to Design and Evaluate Research in Education (8th ed). NY: McGraw Hill.

[18] Garg, S., \& Gautam, A. (2015). Learning English Can Change Your Life for the Better. International Journal English Language, Literature and Humanities, 3, 560-568. http://ijellh.com/papers/2015/April/58-560-568-April-2015.pdf

[19] Ghavifekr, S., Kunjappan, T., Ramasamy, L., \& Anthony, A. (2016). Teaching and learning with ICT tools: Issues and challenges from teachers' perceptions. Malaysian Online Journal of Educational Technology, 4, 38-57.

[20] Gopal, K. \& Wei, B. Q. (2018). Encouraging Teenagers to Improve Speaking Skills through Games in Community College. National Conference on the Sciences and Social Sciences 2018 (Nacoss '18). USIM, Nilai, Malaysia, pp.219-229. 
https://www.researchgate.net/publication/325203233_ENCOURAGING_STUDENTS_TO_IMPROVE_SPEAKING_SKILLS_ THROUGH_SNAKE_AND_LADDER_GAME_IN_COMMUNITY_COLLEGE

[21] Halili, H.H \& Sulaiman, H. (2018). Factors Influencing The Rural Students' Acceptance of Using ICT For Educational Purposes. Kasetsart Journal of Social Sciences. 40, 574-579. https://doi.org/10.1016/j.kjss.2017.12.022

[22] Hall, J. (n.d.). If You Want to Be More Strategic, Start by Playing Games. Inc. https://www.inc.com/john-hall/how-playing-board-games-canmake-you-a-more-strategic-teammate.html

[23] Harmer, J. (2016). The Practice of English Language Teaching. Applied Linguistic and TESOL (5th Ed). Canada: ELT Practice.

[24] Hyndman, B. (2018). Ten reasons teachers can struggle to use technology in the classroom. The Conversation.

https://theconversation.com/ten-reasons-teachers-can-struggle-to-use-technology-in-the-classroom-101114

[25] Kementerian Pendidikan Malaysia. (n.d.). Kurikulum Standard Sekolah Rendah. English Language Scheme of Work: Primary Year 3 SK. Portal Rasmi Bahagian Pembangunan Ku-rikulum. http://bpk.moe.gov.my/index.php/terbitan-bpk/bahan-sokongan/category/386-tahun-3

[26] Larasati, N., Faridi, A. \& Rohani. (2019). The Effectiveness of Simulation Board Game to Improve Speaking Skill in Descriptive Text to the Tenth Grade Students of SMA Negeri 2 Wonosobol. Journal of English Language Teaching, 7, 82-89. https://doi.org/10.15294/elt.v7 i2.28861 [27] Marzano, R. J. (2007). The Art and Science of Teaching: A Comprehensive Framework for Effective Instruction. USA: ASCD.

[28] Mayer, B., \& Harris, C. (2002). Libraries Got Games. Chicago: American Library Association.

[29] Mei, Y.Y., \& Yu-Jing, J. (2000). Using Games in an EFL Class for Children. Daejin Univer-sity ELT Research Paper.

[30] Ministry of Education Malaysia. (2015b). The English Language Roadmap 2015-2025. Ministry of Education Malaysia.

[31] Myhill, D., Jones, S., Lines, H. \& Watson, A. (2012). Re-thinking Grammar: The Impact of Embedded Grammar Teaching on Children's Writing and Children's Metalinguistic Under-standing. Research Paper in Education, 21, 139-166. https://doi.org/10.1080/02671522.2011. 637640

[32] Noori, S. A. S. M. \& Ng, L. L. (2013). Investigating Foreign Students' Language Learning Beliefs in Relation to Their Perceptions of English Language Learning Experiences in Malaysia. In N. Idris (Ed.), Education for All: Malaysian Perspective (pp. 180-188). Tanjong Malim, Malaysia: Universiti Pendidikan Sultan Idris.

[33] Petrova, K., Romaniello, A., Medlin, B., \& Vannoy, S. (2016). QR Codes Advantages and Dangers. Proceedings of the 13th International Joint Conference on e-Business and Tele-communications (ICETE 2016), 2, 112-115. doi: 10.5220/000599310 1120115

[34] Putri, A. A. (2018). The Implementation of Board Game in Improving Students' Speaking Skill in The First Year of SMA N 7 Bandar Lampung In Academic Year 2016/2017 [Unpublished Undergraduate Thesis, University of Lampung]. http://digilib.unila.ac.id/30285/

2/A\%20SCRIPT\%20TANPA\%20BAB\%20PEMBAHSAN.pdf.

[35] Rahmawati, I. N. (2012). Improving the Fourth Grade Students' Speaking Skills Through Board Games [Unpublished Undergraduate Thesis, SD Muhammadiyah Pepe Bantul Yogya-karta]. http:// eprints.uny.ac.id/id/eprint/8260

[36] Resnick, M. (2007). Sowing Seeds For A More Creative Society. Learning and Leading with Technology, December/January 2007-08, 18-22. https://web.media.mit.edu/ mres/papers/Learning-Leading-final.pdf

[37] Rikala, J., \& Kankaanranta, M. (2012). The Use of Quick Response Codes in the Classroom. 11th Conference on Mobile and Contextual Learning, 148-155.

[38] Schmitt, N. (2010). Researching Vocabulary: A Vocabulary Research Manual. 1st Ed. PM. In Fotini, G. \& Makrina, Z. (2017). Adapting Board Games to Stimulate Motivation in Vocabulary Learning in Six Year Old - A Case Study. Journal of Studies in Education. 7, 1-28.

https://doi.org/10.5296/jse. v7i3.11323

[39] Smith, H. (2006). Playing to Learn: A Qualitative Analysis of Bilingual Pupil - Pupil Talk During Board Game Play. Language and Education, 20, 415-437. doi: 10.2167/le639.0

[40] Sujay K. S. \& Smriti, S. (2016). Collaborative Learning Through Language Games in ESL Classroom. Language in India, 16, 180-189.

http://www.languageinindia.com/oct2016/skseslgames.pdf

[41] Schwarz, R. \& Braff, E. (2011). We're No Fun Anymore: Helping Couples Cultivate Joyful Marriages Through the Power of Play (1st ed).

Routledge. https://doi.org/10.4324/9780 203807897

[42] Yong, M. F \& Yeo, L. M. (2016). Effects of Board Game on Speaking Ability of Low-Proficiency ESL Learners. International Journal of Applied Linguistics \& English Literature, 5, 261-271. doi: 10.7575/aiac.ijalel.v.5n.3p.261

[43] Yunus, M. M. (2007). Malaysian ESL Teachers' Use of ICT in Their Classrooms: Expecta-tions and Realities. ReCALL, 9, 79-95. doi:10.1017/s0958344007000614

[44] Yunus, M. M., Lubis, M. A., \& Chua, P. L. (2009). Language Learning Via ICT: Uses, Chal-lenges And Issues. WSEAS Transactions on Information Science and Application, 9, 1453-1467. http://wseas.us/e-library/transactions/information/ 2009/29-575.pdf

[45] Yunus, M. M., Nordin, N., Salehi, H., Sun, C. H., \& Embi, M. A. (2013). Pros and Cons of Using ICT in Teaching ESL Reading and Writing. International Education Studies, 6, 119-130. doi: 10. 55 39/ies.v6n7p119

[46] Yunus, M. M, \& Suliman, A. (2014). Information \& Communication Technology (ICT) Tools in Teaching and Learning Literature Component in Malaysian Secondary Schools. Asian Social Sciences, 10, 136-152. doi: 10.5539/ass.v10n7p136

[47] Yunus, M. M., \& Azman, M. A. (2019). Memory Stay or Stray?: Irregular Verbs Learning Using Kahoot!. Arab World English Journal (AWEJ), 5 , 206-219. https://dx.doi.org/10.240 93/awej/cal 15.15

[48] Zander, M. (2019). The Surprising Benefits Your Kids Get From Playing Board Games. Scholastic. https://www.scholastic.com/parents/kidsactivities-and-printables/activities-for-kids/arts-and-craft-ideas/benefits-board-games.html

[49] Zulkhairi, M. D., Azizah, A., Razak, A., A., \& Rafidah, A. R. (2010). Community Informatics: Success factors at a Rural Community Telecentre, Proceeding of Rural ICT Development 3rd National Conference on Rural ICT Development, Nov. 23/25, 2010, UUM Sintok, Malaysia.

http://www.moe.gov. my/userfiles/file/PPP/Preliminary-Blueprint-Eng.pdf. 